\title{
IMPLEMENTASI TUGAS PENGAMANAN DILEMBAGA PEMASYARAKATAN KELAS IIB CIANJUR DALAM KEADAAN OVER CROWDED
}

\author{
Zeland Muhammad Barr ${ }^{1}$, Padmono Wibowo ${ }^{2}$ \\ ${ }^{1}$ Prodi Manajemen Pemasyarakatan,Politeknik Ilmu Pemasyarakatan, email: \\ zelandmuhammad@gmail.com \\ ${ }^{2}$ Prodi Manajemen Pemasyarakatan,Politeknik Ilmu Pemasyarakatan
}

\begin{abstract}
ABSTRAK
Penelitian ini bertujuan untuk menggambarkan tentang pelaksanaan proses pengamanan di Lembaga Pemasyarakatan kelas IIB Cianjur, serta untuk mengetahui faktor-faktor yang menjadi penghambat penghambat dalam proses pengamanan di Lembaga Pemasyarakatan Kelas IIB Cianjur. Metode yang digunakan dalam penelitian ini dengan menggunakan metode kualitatif deskriptif. Sedangkan jenis Teknik pengumpulan data yang digunakan yaitu dengan cara study pustaka dan wawancara. Hasil penelitian ini menunjukan bahwa proses pelaksanaan tugas pengamanan di Lembaga Pemasyarakatan Kelas IIB Cianjur sudah menunjukan hasil yang cukup baik. Namun masih terkendala pada beberapa faktor penghambat seperti sarana dan prasarana pengamanan, serta alokasi dana yang kurang untuk pemenuhan fasilias pengamanan di Lapas Kelas IIB Cianjur.
\end{abstract}

\section{ARTICLE INFO}

\section{Kata Kunci:}

pengamanan lapas;

Over Crowded

Cite this paper:

Zeland Muhammad

Barr, P. W., 2020.

Implementasi Tugas

Pengamanan

Dilembaga

Pemasyarakatan Kelas

Iib Cianjur Dalam

Keadaan Over

Crowded. Widya

Yuridika: Jurnal Hukum,

3(2).

\section{PENDAHULUAN}

Lembaga Pemasyarakatan yang selanjutnya disebut LAPAS adalah tempat untuk melaksanakan pembinaan Narapidana dan Anak Didik Pemasyarakatan. ${ }^{1}$ Lembaga Pemasyarakatan merupakan sebuah institusi korektif, sebagai bagian akhir dari sistem peradilan pidana. Lapas adalah tempat memperoses (memperbaiki) seseorang dimana input maupun output-nya adalah manusia yang dilabelkan sebagai "penjahat". Lapas tidak mempunyai hak menyeleksi individu yang akan masuk kedalamnya, ini yang

${ }^{1}$ Indonesia, R. (1995). UU 12 tahun 1995. www.bphn.go.id 
membedakan lapas dengan institusi-institusi lainnya seperti perusahaan atau organisasi kemasyarakatan, yang dapat melakukan seleksi input terlebih dahulu.

Namun dalam pelaksanaan proses pembinaan di Lapas sering terjadinya gangguan keamana seperti terjadinya keributan dan pelarian yang terjadi pada tanggal 11 April 2020 di Lapas kelas IIA Manado Sulawesi Utara terjadi keributan di dalam lembaga pemasyarakatan yang dipicu oleh Seorang warga binaan yang meminta dibebaskan sesuai peraturan menteri hukum dan Ham nomor 10 tahun 2020 . para warga binaan narkoba merasa di anak tirikan sehingga meminta disamakan dengan warga binaan lainnya arti warga binaan tindak pidana umum lainnya, Selain itu pemicu keributan lainnya yaitu petugas Lapas khawatir mengenai wabah covid-19 maka dari itu tidak mengizinkan salah satu warga binaan untuk melayat orang tuanya yang meninggal dunia. Karena pada dasarnya melayat keluarga kandung seperti adik, kakak serta orang tua merupakan hak seorang narapidana untuk mengunjungi ketika keadaan meninggal.

Urgensi diterapkannya proses pengamanan di lembaga pemasyarakatan sangat perlu untuk ditingkatkan guna meningkatkan kualitas pengamanan di lembaga pemasyarakatan agar meminimalisir terjadinya gangguan Kamtib seperti pelarian yang terjadi di lembaga pemasyarakatan kelas 1 Tangerang yang serta meningkatkan kualitas Lembaga Pemasyarakatan dalam menjalankan pembinaan serta pembimbingan di lembaga pemasyarakatan guna menyadari kesalahan, menyadari kesalahannya dan tidak mengulangi sesuatu yang telah dibuat serta dapat kembali kepada lingkungan masyarakat yang sesuai dengan tujuan dari undang-undang Pemasyarakatan Nomor 12 Tahun 1995.

Dengan keadaan over crowded pada Lembaga Pemasyarakatan akan sangat berpengaruh terhadap kondisi keamanan Lapas, karena dengan keadaan seperti ini untuk menghirup oksigenpun saling berebut karena keadaan kamar hunian yang sangat bertumpuk serta tidur pun harus saling bergantian karena saking padatnya kondisi kamar hunian. Dengan keadaan demikian Lembaga Pemasyarakatan di Indonesia sangat berkemungkinan besar untuk terjadinya gangguan kamtib.

Dengan demikian Lembaga Pemasyarakatan yang ada di Indonesia perlu meningkatkan serta melaksanakan aturan dan SOP yang ada, agar proses pengamanan yang di laksanakan di Lapas dapat berjalan dengan baik. Penelitian ini bertujuan untuk menggambarkan bagaimana proses pengamanan di Lembaga Pemasyarakatan untuk mencegah terjadinya gangguan kamtib seperti keributan dan pelarian serta bertujuan untuk mengetahui faktor-faktor apa saja yang menjadi penghambat dalam proses pengamanan di Lembaga Pemasyarakatan Kelas IIB CIanjur.

Penilitian ini menggunakan metode kualitatif bersifat deskriptif dengan pengambilan data menggunakan studi pustaka (library research), dengan jenis penelitian hukum normatif, yaitu suatu penelitian yang mengkaji mengenai asas-asas hukum, sistematika hukum, taraf sinkronisasi hukum. Namun pada kali ini penulis lebih tertarik lagi mengkaji terhadap asas-asas hukum. Penelitian terhadap asas-asas hukum dilakukan terhadap kaidah-kaidah hukum yang merupakan patokan-patokan berprilaku atau 
bersikap tidak pantas. Penelitian tersebut dapat dilakukan (terutama) terhadap bahan hukum primer dan sekunder. ${ }^{2}$

Sumber data yang digunakan oleh penulis dalam penelitian ini adalah sumber data sekunder. Adapun data sekunder di dalam penelitian ini dapat dibedakan menjadi 2, yakni:

a. Bahan Hukum Primer, yaitu bahan hukum yang mengikat yang dapat terdiri dari:

- Undang-Undang Dasar Republik Indonesia Tahun 1945.

- Undang-Undang Nomor 12 Tahun 1995 tentang Pemasyarakatan.

- Permenkumham No 33 Tahun 2015 Tentang Pengamanan pada Lapas dan Rutan

b. Bahan Hukum Sekunder, yaitu bahan hukum yang memberikan penjelasan mengenai bahan hukum primer, misalnya:

- Buku-buku literatur yang berhubungan dengan permasalahan pengamanan Lapas

- Makalah-makalah/jurnal/karya tulis yang berkaitan dengan pengamanan Lapas

Hasil penelitian para pakar hukum/lembaga yang bergerak dalam penelitian tersebut.

\section{HASIL DAN PEMBAHASAN}

\section{A. Pentingnya Proses pengamanan di Lembaga Pemasyarakatan Kelas IIB Cianjur}

Pengamanan Lembaga Pemasyarakatan mengacu pada visiNegara Republik Indonesia yang dirumuskan pada pembukaan UUD 1945. Pada pembukaan undangundang dasar tahun 1945 dinyatakan bahwa tujuan negara Indonesia untuk melindungi segenap bangsa Indonesia, memajukan kesejahteraan umum mencerdaskan kehidupan bangsa dan ikut melaksanakan ketertiban dunia demi mewujudkan keadilan sosial bagi seluruh rakyat Indonesia, begitupun pada Lembaga pemasyarakatan didalamnya terdapat Narapidana yang merupakan anggota masyarakat yang mempunyai hak untuk mendapatkan pelindungan keamanan ${ }^{3}$

menurut undang-undang Pemasyarakatan pasal 1 angka 3 Lapas merupakan tempat untuk melaksanakan pembinaan narapidana dan anak didik Pemasyarakatan. Sistem Pemasyarakatan di samping bertujuan untuk mengembalikan warga binaan Pemasyarakatan sebagai warga yang baik namun juga bertujuan untuk melindungi masyarakat terhadap kemungkinan diulangnya tindak pidana oleh warga binaan Pemasyarakatan, serta merupakan penerapan dan bagian yang tak terpisahkan dari nilai-nilai yang terkandung dalam Pancasila. ${ }^{4}$

Selain itu Lembaga Pemasyarakatan merupakan suatu institusi pemerintah yang sangat rentan akan terjadinya sebuah pelanggaran kerusuhan dan penyimpangan

\footnotetext{
2 Soerjono Soekanto dan Sri Mamudji, Penelitian Hukum Normatif : Suatu Tinjauan Singkat, PT Rajagrafindo Persada, Jakarta, 2006, hlm. 62.

${ }^{3}$ Nri.Undang-undang Dasar Negara Republik Indonesia Tahun 1945

${ }^{4}$ Ningrum, R. A. (2016). Urgensi pengaturan keamanan dan ketertiban dalam lembaga permasyarakatan di indonesia. Urgensi

Pengaturan Keamanan Dan Ketertiban Dalam Lembaga Pemasyarakatan Di Indonesia.

http://hukum.studentjournal.ub.ac.id/index.php/hukum/article/viewFile/750/737
} 
lainnya yang mengancam keamanan yang bersifat individual maupun kelembagaan dengan ini sangat penting akan peran petugas pengamanan untuk menjaga stabilitas keamanan agar situasi dan kondisi Lembaga Pemasyarakatan tetap kondusif karena Ketika suatu lembaga pemasyarakatan situasi dan kondisi yang tidak aman maka pembinaan sebagai wujud dari program untuk mengembalikan narapidana yang tersesat kembali kepada jalan yang benar serta mengembalikan dan membaurkan narapidana di lingkungan masyarakat sebagai manusia seutuhnya dan merubahnya menjadi manusia yang lebih baik sebagai wujud dari tujuan Pemasyarakatan maka dari itu erat kaitannya antara fungsi keamanan lapas dengan keberhasilan pembinaan yang ada di Lapas.

Lembaga Pemasyarakatan sebagai institusi reintegrasi sosial merupakan tempat untuk mengembalikan narapidana kembali bersosialisasi di tengah masyarakat sebagai manusia seutuhnya dan menyadari kesalahan hal ini tertuang dalam pasal 2 undang-undang Nomor 12 Tahun 1995 tentang Pemasyarakatan, namun dalam proses pembinaan dibutuhkannya situasi dan suasana kondusif di lembaga pemasyarakatan agar terciptanya suasana yang kondusif dibutuhkan keadaan yang aman serta tertib. Ketika adanya sebuah gangguan keamanan dan ketertiban maka kegiatan pembinaan yang dilakukan di dalam lembaga pemasyarakatan akan terganggu dan tidak akan maksimal maka dari itu pemeliharaan keamanan merupakan suatu hal yang sangat penting yang harus diterapkan di dalam Lapas guna melindungi penghuninya baik Narapidana maupun petugas.

Maka dari itu aspek keamanan sangat perlu untuk diperhatikan karena aman atau tidak amannya suatu lembaga pemasyarakatan akan berpengaruh terhadap pola pembinaan yang diterapkan dan akan berpengaruh pada setiap aspek yang ada.

\section{B. Pelaksanaan proses Pengamanan yang dilakukan di Lembaga Pemasyarakatan Kelas IIB Cianjur sesuai dengan SOP Pengaturan pengamanan.}

Pelaksanaan proses pengamanan di Lembaga Pemasyarakatan yang baik harus sesuai dengan Permenkumham no 33 tahun 2015 tentang pengamanan pada Lembaga Pemasyarakatan dan Rumah tahanan Negara menyatakan sebagai berikut:

Pasal 6 : Penyelenggaraan Pengamanan sebagaimana dimaksud dalam Pasal 4 ayat (1) mencakup kegiatan: a. pencegahan b. penindakan dan c. pemulihan.

Pasal 7 : Dalam melaksanakan Pengamanan pada Lapas atau Rutan harus dilengkapi dengan sarana dan prasarana Pengamanan.

Pasal 8 : Pencegahan Gangguan Keamanan dan Ketertiban pada Lapas atau Rutan, meliputi:

a. pemeriksaan pintumasuk b. Penjagaan c. Pengawalan d.Penggeledahan e. Inpeksi

f. Kontrol g. kegiatan Intelijen h. pengendalian peralatan i. pengawasan komunikasi j. pengendalian lingkungan $\mathrm{k}$. penguncian l. penempatan dalam rangka Pengamanan $m$. investigasi dan reka ulang $n$. tindakan lain sesuai dengan ketentuan peraturan perundang-undangan.

Pasal 9 
1. Pemeriksaan terhadap pintu masuk sebagaimana dimaksud dalam Pasal 8 huruf a merupakan pemeriksaan administrasi yang dilakukan terhadap orang yang akan memasuki halaman Lapas atau Rutan.

2. Pemeriksaan sebagaimana dimaksud pada ayat (1) dilakukan oleh Satuan Pengamanan.

Dalam pelaksanaannya proses pengamanan di Lembaga Pemasyarakatan Kelas IIB Cianjur sudah cukup baik untuk memenuhi standar pengamanan sesuai permenkumham no 33 Tahun 2015. Namun masih ada beberapa factor yang yang menyebabkan proses pengamanan belum bisa terlaksana dengan maksimal hal ini disebabkan oleh beberapa factor diantaranya ketersediaan fasilitas penunjang keamanan.

Dengan demikian untuk memaksimalkan proses pengamanan pada Lembaga Pemasyarakatan kelas IIB Cianjur perlu ditingkatkannya fasilitas pengamanan seperti CCTV pada setiap sudut Lapas, serta alat deteksi barang disediakan di bagian pintu penjagaan utama untuk mendeteksi barang apa saja yang masuk ke dalam Lapas untuk meminimalisir masuknya barang terlarang seperti narkotika dan senjata tajam.

\section{Pelaksanaan pengamanan Lapas berdasarkan Undang-undang Pemasyarakatan}

Proses pengamanan merupakan hal yang wajib untuk dilaksanakan tanpa terkecuali karena kondisi keamanan Lapas akan berdampak pada proses pembinaan terhadap Narapidana, karena dengan keadaan Lapas yang tidak aman mustahil akan berjalannya pembinaan yang sesuai dengan harapan yang tertuang pada Undang-undang No 12 Tahun 1995.

Secara khusus pelaksanaan proses pengamanan telah diatur dalam berbagai instrument hukum Nasional antara lain :

\section{Undang undang No 12 Tahun 2015 Tentang pemasyarakatan} Pasal 46:

Kepala LAPAS bertanggung jawab atas keamanan dan ketertiban di LAPAS yang dipimpinnya.

\section{Pasal 47}

1. Kepala LAPAS berwenang memberikan tindakan disiplin atau menjatuhkan hukuman disiplin terhadap Warga Binaan Pemasyarakatan yang melanggar peraturan keamanan dan ketertiban di lingkungan LAPAS yang dipimpinnya.

2. Jenis hukuman disiplin sebagaimana dimaksud dalam ayat (1) dapat berupa:

a. tutupan sunyi paling lama 6 (enam) hari bagi Narapidana atau Anak Pidana

b. menunda atau meniadakan hak tertentu untuk jangka waktu tertentu sesuai dengan peraturan perundang-undangan yang berlaku.

3. Petugas pemasyarakatan dalam memberikan tindakan disiplin atau menjatuhkan hukuman disiplin sebagaimana dimaksud dalam ayat (1) wajib:

a. memperlakukan Warga Binaan Pemasyarakatan secara adil dan tidak bertindak sewenang-wenang

b. mendasarkan tindakannya pada peraturan tata tertib LAPAS.

4. Bagi Narapidana atau Anak Pidana yang pernah dijatuhi hukuman tutupan sunyi sebagaimana dimaksud dalam ayat (2) huruf a, apabila mengulangi pelanggaran 
atau berusaha melarikan diri dapat dijatuhi lagi hukuman tutupan sunyi paling lama 2 (dua) kali 6 (enam) hari.

Dalam pelaksanaannya Lapas Kelas IIB Cianjur menerapkan hukuman disiplin terhadap para Narapidana yang melanggar ketentuan dengan dimasukannya di sel khusus sebagai teguran agar narapidana tersebut tidak melakukan kembali pelanggaran yang pernah dilakuakan.

Pasal 48 : Pada saat menjalankan tugasnya, petugas LAPAS diperlengkapi dengan senjata api dan sarana keamanan yang lain.

Pasal 49 : Pegawai Pemasyarakatan diperlengkapi dengan sarana dan prasarana lain sesuai dengan kebutuhan dan peraturan perundang-undangan yang berlaku.

Dalam pelaksanaan tugasnya para petugas dilengkapi sarana dan prasarana pendukung yang diguankaan untuk proses pengamanan seperti CCTV yang berguna untuk memudahkan dalam memantau sistuasi Lapas, serta dalam mengecek apa saja barang yang masuk kedalam lapas dengan menggunakan X-ray dan body scanner. Dalam pada Lapas Cianjur pengguanaan CCTV belum seluruhnya tersebar pada setiap sudut Lpas serta pengguanaan Body scanner yang belum tersedia yang berkaitan dengan tidak cukupnya anggaran untuk membeli peralatan.

Pasal 50 : Ketentuan mengenai keamanan dan ketertiban LAPAS diatur lebih lanjut dengan Keputusan Menteri.

\section{Permenkumham No 33 Tahun 2015 Tentang pengamanan pada Lapas dan Rutan}

1. Lembaga Pemasyarakatan yang selanjutnya disebut Lapas adalah tempat untuk melaksanakan pembinaan Narapidana dan Anak Didik Pemasyarakatan.

2. Rumah Tahanan Negara yang selanjutnya disebut Rutan adalah tempat tersangka atau terdakwa ditahan selama proses penyidikan, penuntutan, dan pemeriksaan di sidang pengadilan.

3. Narapidana adalah terpidana yang menjalani pidana hilang kemerdekaan di dalam Lapas.

4. Tahanan adalah seorang tersangka atau terdakwa yang ditempatkan di dalam Rutan.

5. Petugas Pemasyarakatan adalah Pegawai Negeri Sipil yang melaksanakan tugas di bidang Pemasyarakatan.

6. Pengamanan Lapas atau Rutan yang selanjutnya disebut Pengamanan adalah segala bentuk kegiatan dalam rangka melakukan pencegahan, penindakan dan pemulihan terhadap setiap gangguan keamanan dan ketertiban di Lapas atau Rutan.

7. Satuan Pengamanan adalah unit yang memiliki tugas melakukan pencegahan, penindakan, penanggulangan dan pemulihan gangguan keamanan dan ketertiban di Lapas dan Rutan.

8. Kepala Satuan Pengamanan adalah petugas pengamanan yang berada dibawah dan bertanggung jawab langsung kepada Kepala Lapas atau Rutan.

Pada BAB II PENYELENGGARAAN PENGAMANAN di terangkan pada:

\section{Pasal 2}

1. Menteri berwenang menyelenggarakan Pengamanan. 
2. Kewenangan sebagaimana dimaksud pada ayat (1) dilaksanakan oleh Direktur Jenderal Pemasyarakatan.

3. Direktur Jenderal Pemasyarakatan sebagaimana dimaksud pada ayat (2) melimpahkan kewenangan pelaksanaan Pengamanan kepada Kepala Divisi Pemasyarakatan melalui Kepala Kantor Wilayah Kementerian Hukum dan Hak Asasi Manusia.

4. Kepala Divisi Pemasyarakatan sebagaimana dimaksud pada ayat (3) melimpahkan kewenangan dan tanggung jawab pelaksanaan Pengamanan kepada Kepala Lapas atau Rutan.

Pasal 3

1. Dalam menyelenggarakan Pengamanan sebagaimana dimaksud dalam Pasal 2 dapat dibentuk satuan tugas keamanan dan ketertiban.

2. Pembentukan satuan tugas keamanan dan ketertiban sebagaimana dimaksud pada ayat (1) dilakukan oleh:

a. Direktur Jenderal Pemasyarakatan untuk satuan tugas keamanan dan ketertiban di tingkat pusat

b. Kepala Kantor Wilayah Kementerian Hukum dan Hak Asasi Manusia untuk satuan tugas keamanan dan ketertiban di tingkat wilayah provinsi.

Pasal 4

1. Pengamanan dilaksanakan berdasarkan klasifikasi:

a. Pengamanan sangat tinggi

b. Pengamanan tinggi

c. Pengamanan menengah

d. Pengamanan rendah.

2. Klasifikasi Pengamanan sebagaimana dimaksud pada ayat (1) didasarkan pada:

a. pola bangunan

b. pengawasan.

3. Pelaksanaan klasifikasi Pengamanan sebagaimana dimaksud pada ayat (2) meliputi:

a. Pengamanan sangat tinggi dilengkapi dengan pemagaran berlapis, pos menara atas, pos bawah, penempatan terpisah, pengawasan closed circuit television, pembatasan gerak, pembatasan kunjungan dan pembatasan kegiatan pembinaan, serta pengendalian komunikasi

b. Pengamanan tinggi dilengkapi dengan pemagaran berlapis, pos menara atas penempatan terpisah atau bersama, pengawasan closed circuit television, pembatasan gerak, pembatasan kunjungan, dan kegiatan pembinaan

c. Pengamanan menengah dilengkapi dengan pemagaran minimal 1 (satu) lapis, penempatan terpisah atau bersama, pengawasan closed circuit television, pembatasan kunjungan dan pembatasan kegiatan pembinaan dan

d. Pengamanan rendah tanpa pemagaran berlapis, penempatan terpisah dan bersama, pengawasan closed circuit television dan pembatasan kegiatan pembinaan.

Lapas Kelas IIB Cianjur dikategorikan sebagai Lapas dengan klasifikasi lapas dengan pengamanan menengah yang sesuai dalam pembagian klasifikasi paada premenkumham no 33 Tahaun 2015 pada pasal 4 tentang klasifikasi pengamanan Lapas. Pengklasifikasian Lembaga pemasyarakatan berdasarkan struktur bangunan serta 
struktur pengamanan yang ada Pada Lapas. Selain itu klasifikasi Narapidana seperti lamanya masa tahanan.

\section{Pasal 5 :}

Dalam menyelenggarakan Pengamanan terhadap Narapidana dan Tahanan wanita dilakukan dengan mengutamakan keberadaan petugas wanita.

Pasal 6

Penyelenggaraan Pengamanan sebagaimana dimaksud dalam Pasal 4 ayat (1) mencakup kegiatan:
a. pencegahan
b. penindakan
c. pemulihan.

Dalam proses pengamanaan Lapas Kelas IIB Caianjur melakukan pencegahan terjadinya gangguan kamtib dengan melakukan penguatan pengamanan serta peningkatan fasilitas pengamanan dengan menambah sumber cahaya peneranagan guana meminimalisir terjadian pelarian yang dilakukan Narapidana. Serta fasilitas pendukung lainnya

Selain itu penindakan selalu dilakukan oleh Lapas kelas IIB Cianjur kepada warga binaan yang melakukan pelanggaran seperti berkelahi, menggunakan Narkotika dll dengan cara memasukannya ke Sel serta memasukannya pada register F.

Pasal 7

Dalam melaksanakan Pengamanan pada Lapas atau Rutan harus dilengkapi dengan sarana dan prasarana Pengamanan. Bagian Kedua Pencegahan

Pasal 8

Pencegahan Gangguan Keamanan dan Ketertiban pada Lapas atau Rutan, meliputi:

a. pemeriksaan pintu masuk

b. Penjagaan

c. Pengawalan

d. Penggeledahan

e. Inpeksi

f. Kontrol

g. kegiatan Intelijen

h. pengendalian peralatan

i. pengawasan komunikasi

j. pengendalian lingkungan

k. penguncian

l. penempatan dalam rangka Pengamanan

m. investigasi dan reka ulang

n. tindakan lain sesuai dengan ketentuan peraturan perundang-undangan.

Pasal 9 
1. Pemeriksaan terhadap pintu masuk sebagaimana dimaksud dalam Pasal 8 huruf a merupakan pemeriksaan administrasi yang dilakukan terhadap orang yang akan memasuki halaman Lapas atau Rutan.

2. Pemeriksaan sebagaimana dimaksud pada ayat (1) dilakukan oleh Satuan Pengamanan.

Pasal 10

1. Penjagaan sebagaimana dimaksud dalam Pasal 8 huruf b dilakukan di:

a. pintu gerbang halaman

b. pintu gerbang utama

c. pintu Pengamanan utama

d. ruang kunjungan

e. lingkungan blok hunian

f. blok hunian

g. pos menara atas

h. area lainnya yang ditetapkan oleh Kepala Lapas atau Rutan.

2. Penjagaan sebagaimana dimaksud pada ayat (1) dilakukan oleh Regu Pengamanan.

Pada proses penagmanan lapas Cianjur membuat regu jaga dalam setiap pos penjagaan yang tertera pada pasal 10 ayat 1 secara bergiliran.

Pasal 11

1. Pengawalan sebagaimana dimaksud dalam Pasal 8 huruf c dilakukan terhadap Narapidana atau Tahanan pada saat :

a. izin luar biasa

b. cuti mengunjungi keluarga

c. asimilasid roses peradilan

e. pemindahan

f. perawatan medis di luar Lapas atau Rutan

g. kebutuhan lainnya sesuai dengan ketentuan peraturan perundangundangan.

2. Pengawalan sebagaimana dimaksud pada ayat (1) dilakukan oleh Satuan Pengamanan atas izin dari Kepala Lapas atau Rutan.

Pada proses penagawalan Lapas Kelas IIB Cianjur melakukannya kepada setiap wargabinaan yang melakukan izin kelluar dengna berbagai alasan yang tertera diatas dengan didampingi oleh Staf KPLP sebagai penagaman untuk mencegah terjadinya pelarian.

Pasal 12

1. Penggeledahan sebagaimana dimaksud dalam Pasal 8 huruf d meliputi:

a. Penggeledahan badan

b. Penggeledahan barang

c. Penggeledahan sel

d. Penggeledahan area

e. Penggeledahan kendaraan.

2. Penggeledahan sebagaimana dimaksud pada ayat (1) dilakukan oleh:

a. anggota Satuan Pengamanan dan pegawai yang ditunjuk 
b. satuan tugas keamanan dan ketertiban dari Divisi Pemasyarakatan pada Kantor Wilayah Kementerian Hukum dan Hak Asasi Manusia

c. satuan tugas keamanan dan ketertiban dari Direktorat Jenderal Pemasyarakatan.

Pasal 16

1. Pengendalian peralatan sebagaimana dimaksud dalam Pasal 8 huruf h dilakukan dengan mengelola seluruh sarana Pengamanan dan sarana lain yang dapat menyebabkan timbulnya Gangguan Keamanan dan Ketertiban.

2. Sarana Pengamanan sebagaimana dimaksud pada ayat (1) meliputi:

a. senjata api

b. peralatan huru hara

c. kunci dan gembok

d. peralatan komunikasi

e. ruang kontrol

f. alat pemadam kebakaran

g. kendaraan.

Dengan adanya pengaturan yang berkaitan dengan proses pengamanan Lapas dapat menjadikan sebagai pedoman para petugas Lembaga Pemasyaratan dalam menjalankan tugasnya dengan baik serta menjadikan payung hukum bagi petugas dalam menjalankan kinerjanya.

\section{Faktor penghambat dalam pelaksanaan proses pengamanan di Lembaga Pemasyarakatan Kelas IIB Cianjur}

Berdasarkan permasalahan yang ada pada Lembaga Pemasyarakatan yang sudah di Jelaskan di atas faktor penghambat dalam proses pengamanan di Lembaga Pemasyarakatan Kelas IIB Cianjur antara lain:

1. Sarana dan prasarana pengamanan yang masih kurang

Adanya sarana dan prasarana pengamanan yang baik dan lengkap akan berpengaruh terhadap aktivitas Lapas pada seluruh aspek yang ada. Terlebih pada bagian pengamanan yang di lakukan oleh Lembaga Pemasyarakatan Kelas IIB Cianjur. Karena dengan lengkapnya sarana dan prasarana pengamanan maka akan optimal pula dalam menjaga keamanan Lapas. Seperti dengan disediakannya CCTV pada setiap sudut Lapas akan memudahkan para petugas dalam memantau situasi Lapas.

Namun pada Lembaga Pemasyarakatan kelas IIB Cianjur masih kurangnya dalam perlengkapan sarana pendukung pengamanan. seperti masih kurangnya CCTV yang tersebar dalam setiap sudut Lapas, tidak adanya body scenner pada pos pengamanan pintu utama yang mengecek siapa saja yang masuk ke dalam Lapas yang bertujuan untuk meminimalisir terjadinya penyeludupan yang dilakukan oleh pengunjung bahkan Petugas.

2. Pegawai yang kurang berintegritas

Dalam proses pengamnaan yang pertu ada yaitu integritas seorang petugas, karena hal terbesar terjadinya gangguan kamtib pada Lapas sebagian besar ada kaitannya dengan para petugas seperti beredarnya narkotika, Handphone yang terjadi di Lapas para petugas ikut andil dalam penyebarannya hal ini pun masih terjadi di Lapas kelas IIB Cianjur

3. Jumlah petugas dengan Narapidana terlampau jauh 
Jumlah petugas sangat berpengaruh terhadap situasi dan kondisi pada Lapas karena dengan kurangnya petugas akan kurangnya pengawasan yang di lakukan terhadap setiap Narapidana. Hal ini yang terjadi pada Lapas kelas IIB Cianjur jumlah petugaas pengamanan hanya sebanyak 61 orang sedangkan jumalah Narapidana sebanyak 720 orang sesuai data yang diambil pada saat penelitian.

\section{PENUTUP}

Pelaksanaan proses pengamanan pada Lembaga Pemasyarakatan Kelas IIB Cianjur sesuai dengan Permenkumham No 33 tahun 2015 seperti pencegahan terjadinya gangguan kamtib, penindakan serta pemulihan. yang mengacu pada Undang-undang No 12 tahun 1995 Tentang pemasyarakatan. Namun dalam prakteknya masih terjadi beberapa kendala yang menghambat terlaksananya proses pengamanan secara optimal diantaranya yaitu: Sarana dan prasarana pengamanan yang masih kurang seperti kurang tersebarnya CCTV, body scanner dan X-ray yang tidak ada, hal ini sangat mempengaruhi terhadap proses pengaman yang optimal karena fasilitas pendukung seperti yang ada di atas sangat membantu pada pelaksanaan pengamanan. selain itu Pegawai yang kurang berintegritas dan Jumlah petugas dengan Narapidana terlampau jauh sangat berpengaruh terhadap terlaksananya pengamanan yang optimal. Dengan faktor-faktor demikian maka sangat perlu untuk penambahan fasilitas yang baik, jumlah pegawai serta penanaman moral terhadap para pegawai Lapas Kelas IIB Cianjur

\section{DAFTAR PUSTAKA \\ BUKU}

Modul Teknis Pengamanan kepala regu jaga dan Petugas Pintu Utama.kemenkumham

Fuady, Munir, 2007,Dinamika Teori Hukum. Ghalia Indonesia: Bogor.

Kelsen, Hans, 2007, Teori Umum Hukum Dan Negara Bee,Media Indonesia: Jakarta

\section{Perarturan-Perundangan}

Undang-Undang Nomor 12 Tahun 1995 tentang Pemasyarakatan, Lembaran Negara Republik

Permenkumham Nomor 33 Tahun 2015 Tentang pengamanan Lapas dan Rutan

\section{ARTIKEL JURNAL}

Harpe, S. E., Zohrabi, M., Barkaoui, K., Lozano, L. M., García-Cueto, E., Muñiz, J., Menold, N., Kaczmirek, L., Lenzner, T., Neusar, A., Martin-Raugh, M., Tannenbaum, R. J., Tocci, C. M., Reese, C., Reid, R., Dupaul, G. J., Power, T. J., Anastopoulos, A. D., RogersAdkinson, D., ... Schillewaert, N. (2015). No Title)2( $\square \square \square \square \square, \square \square \square \square \square \square$. ثقنق: https://doi.org/10.5897/ERR2015

Ningrum, R. A. (2016). Urgensi pengaturan keamanan dan ketertiban dalam lembaga permasyarakatan di indonesia. Urgensi Pengaturan Keamanan Dan Ketertiban Dalam Lembaga Pemasyarakatan Di Indonesia. http://hukum.studentjournal.ub.ac.id/index.php/hukum/article/viewFile/750/73 7

Novarizal, R., \& Herman, H. (2019). Pengamanan Lembaga Pemasyarakatan Terhadap 
Widya Yuridika: Jurnal Hukum, Volume 3 / Nomor 2 / Desember 2020

Kemungkinan Terjadinya Pelarian (Studi Kasus Lapas Kelas II A Pekanbaru). Sisi Lain Realita, 4(1), 90-102.

https://doi.org/10.25299/sisilainrealita.2019.vol4(1).4051

Yahya, A. Z. (2013). Problematika Pengamanan Narapidana dan Tahanan di Lembaga Pemasyarakatan Tarakan. Pandecta: Research Law Journal, 6(1). https://doi.org/10.15294/pandecta.v6i1.2324

Jenni, F. (2017). Fakultas dakwah dan komunikasi universitas islam negeri raden fatah palembang 2016. 15-16. 